\title{
A survey of the main technology, biochemical and microbiological features influencing the concentration of biogenic amines of twenty Apulian and Sicilian (Southern Italy) cheeses
}

\author{
Rosa Guarcello a, Annamaria Diviccaro ${ }^{\text {b }}$, Marcella Barbera ${ }^{\text {a }}$, Elena Giancippoli ${ }^{\text {b }}$, \\ Luca Settanni ${ }^{\text {a }}$, Fabio Minervini ${ }^{\text {b, }}$, Giancarlo Moschetti ${ }^{a}$, Marco Gobbetti ${ }^{\text {b }}$ \\ a Department of Agricultural and Forest Science, University of Palermo, Viale delle Scienze 4, 90128 Palermo, Italy \\ b Department of Scienze del Suolo, della Pianta e degli Alimenti, University of Bari Aldo Moro, via Amendola 165/a, 70126 Bari, Italy
}

\section{A R T I C L E I N F O}

\section{Article history:}

Received 11 September 2014

Received in revised form

27 November 2014

Accepted 28 November 2014

Available online 5 December 2014

\begin{abstract}
A B S T R A C T
Twenty Apulian and Sicilian cheeses were analysed for their concentrations of eight biogenic amines (BAs), free amino acids, $\mathrm{pH}$, water activity, and subjected to microbiological characterisation. In addition, lactic acid bacteria isolated from cheeses were assayed for their capacity to generate BAs. Principal component analysis was performed to find the effect of different parameters on the distribution of the cheeses. Although short-ripened $(\leq 30 \mathrm{~d})$ cheeses did not show significant BA concentrations, the only BA showing high positive correlation with time of ripening was histamine. Concentration of histidine and, especially, percentage of histidine-decarboxylase bacteria presumably affected histamine concentration. High $\mathrm{pH}$ values were negatively correlated to the concentration of tyramine, putrescine, and cadaverine. Fifty percent of the cheeses contained at least one BA at potentially toxic concentrations. Unambiguous and ever-valid relations among parameters and BAs are difficult to determine, because BAs are the result of combined and varied factors.
\end{abstract}

๑) 2014 Elsevier Ltd. All rights reserved.

\section{Introduction}

Biogenic amines (BAs) are low-molecular nitrogenous organic bases that are formed in foodstuffs by microbial decarboxylation of the precursor amino acids. Tyrosine, histidine, lysine, tryptophan, and phenylalanine are, respectively, precursor amino acids for tyramine, histamine, cadaverine, tryptamine, and 2phenylethylamine. Ornithine and arginine may be the precursors for putrescine, spermidine and spermine. Although small amounts of BAs are biosynthesised in plant and animal cells, having different biological activities (Pinho et al., 2004), these compounds are potentially toxic to human health. The effects on nervous and vascular systems are particularly severe in sensitive people or when the amine oxidases, naturally involved in the detoxification, are inhibited (Shalaby, 1996; Silla Santos, 1996). The toxicity limit of BAs in foods is estimated to be $100 \mathrm{mg} \mathrm{kg}^{-1}$, even though it is stated that the safe sum of histamine, tyramine, putrescine and

\footnotetext{
* Corresponding author. Tel.: +39080 5442950.

E-mail address: fabio.minervini@uniba.it (F. Minervini).
}

cadaverine should not exceed $900 \mathrm{mg} \mathrm{kg} \mathrm{kg}^{-1}$ (Shalaby, 1996; Valsamaki, Michaelidou, \& Polychroniadou, 2000).

Cheeses are among the foods most commonly associated with the presence of BAs (Innocente \& D'Agostin, 2002; Moret, Bortolomeazzi, Feruglio, \& Lerker, 1992; Stratton, Hutkins, \& Taylor, 1991). Indeed, the main biochemical process that takes place during cheese ripening, proteolysis, leads to the accumulation of free amino acids (FAAs), some of which are precursors of BAs. The BA concentration of many typical and/or traditional Italian cheeses was analysed (Innocente, Biasutti, Padovese, \& Moret, 2007; Ladero, Fernández, \& Álvarez, 2009; Martuscelli et al., 2005; Schirone et al., 2013; Spizzirri et al., 2013). Overall, the concentration and type of BAs in cheeses is extremely variable, depending on: (i) type of milk (cows'/sheep's/goats' milk); (ii) thermal treatment of cheese milk; (iii) section of the cheese (edge/core); (iv) ripening conditions; (v) post-ripening processing; (vi) type of packaging; (vii) storage time and temperature; and (viii) microbiota responsible for cheese-making (Loizzo et al., 2013). Generally, the concentration of BAs was lower in short-ripened than in long-ripened cheeses (Bunková et al., 2010; Fernández, Linares, Del Rio, Ladero, \& Alvarez, 2007), where the level of proteolysis and catabolism of 
FAAs increases. Cheeses possess very rich, diverse and complex microbiota, mainly deriving from primary starter lactic acid bacteria and adventitious non-starter lactic acid bacteria (NSLAB; Beresford \& Williams, 2004). High cell densities of NSLAB, possessing amino acid decarboxylating enzymes (e.g., tyrosine decarboxylase), were positively correlated with high content of BAs in cheeses (Bunková et al., 2010; Fernández et al., 2007; Komprda et al., 2008; Ladero et al., 2009; Martuscelli et al., 2005). Nevertheless, the concentration of ethylamine, tryptamine, 2phenylethylamine, and cystamine during ripening of Terrincho cheese, reached the maximum at 30 days, but subsequently decreased, meaning that such compounds are also degraded or transformed (Pinho et al., 2004).

Although, except for histamine in fish products, there is no consensus on the maximum permitted concentration of BAs in foods, everybody acknowledges that reducing the concentration of such potentially toxic compounds in foods is extremely important. The formation of BAs may be limited through the use of either aminenegative (not able to decarboxylate FAAs into BAs) or amine oxidising starter cultures (Bover-Cid, Izquierdo-Pulido, \& Vidal-Carou, 2000, 2001; Latorre-Moratalla et al., 2007; Mah, Kim, \& Hwang, 2009; Spicka, Kalac, Bover-Cid, \& Krizek, 2002; Stratton et al., 1991).

To the best of our knowledge, no studies were focused on the concentration of all of the possible BAs in a high number of traditional cheeses, and looking at this food safety feature as possibly affected by technology parameters, concentration of precursor FAAs and microbiological characteristics. Therefore, the aim of this study was to correlate the content of BAs of twenty traditional Apulian or Sicilian (Southern Italy) cheeses with several technological and microbiological features such as time of ripening, $\mathrm{pH}$, concentration of precursor FAAs, and occurrence of decarboxylasepositive lactic acid bacteria.

\section{Materials and methods}

\subsection{Cheeses}

Nine Apulian (Cacio, Caciocavallo Podolico Dauno, Caciocavallo Silano Protected Designation of Origin (PDO), Cacioricotta, Canestrato Pugliese PDO, Caprino di Biccari, Caprino di Castel Fiorentino, Pecorino Foggiano, and Vaccino), and eleven Sicilian (Caciocavallo Palermitano, Ragusano PDO, Caprino Girgentano, Fior di Capra, Fiore Sicano, Maiorchino, Pecorino Siciliano PDO, Piacentinu Ennese, Provola dei Nebrodi, Tuma Persa, and Vastedda della valle del Belice PDO) traditional cheeses were evaluated in this study. Table 1 summarises the main parameters used during manufacturing and ripening, as well as the approximate moisture level of each cheese. Three batches of each cheese were collected at local dairy farms and kept at $4{ }^{\circ} \mathrm{C}$ during transfer $(1-3 \mathrm{~h}$ ) to laboratory. Each cheese was analysed for BAs, $\mathrm{pH}$, water activity $\left(a_{\mathrm{w}}\right)$, FAAs, and microbiological features.

\subsection{Determination of biogenic amines in cheeses}

BAs were extracted from cheese, derivatised and quantified, according to the method described by Innocente et al. (2007), with modifications. In detail, $10 \mathrm{~g}$ of cheese were weighed in a $50 \mathrm{~mL}$ polypropylene tube and $20 \mathrm{~mL}$ of $0.1 \mathrm{~mol} \mathrm{~L}^{-1} \mathrm{HCl}$ added, containing 1,7-diaminoheptane $\left(0.01 \mathrm{mg} \mathrm{mL}^{-1}\right)$ as the internal standard. The suspension was homogenised for $2 \mathrm{~min}$ in a BagMixer 400P (Interscience, St. Nom, France) blender. The homogenate was centrifuged at $15,557 \times \mathrm{g}$, at $4{ }^{\circ} \mathrm{C}$, for $30 \mathrm{~min}$ and the supernatant (first acid extract) was transferred into a clean $50 \mathrm{~mL}$ polypropylene tube. The pellet was added with $20 \mathrm{~mL}$ of $0.1 \mathrm{~mol} \mathrm{~L}^{-1} \mathrm{HCl}$, containing the internal standard, homogenised and centrifuged as described above. The supernatant (second acid extract) was recovered and mixed with the first acid extract. The two extracts were diluted to $50 \mathrm{~mL}$ with $0.1 \mathrm{~mol} \mathrm{~L}^{-1} \mathrm{HCl}$.

Extracted BAs were derivatised by mixing $1 \mathrm{~mL}$ of extract, $0.5 \mathrm{~mL}$ of saturated $\mathrm{NaHCO}_{3}$ solution and $1 \mathrm{~mL}$ of dansyl chloride (DCl) reagent (dissolved in acetone at $10 \mathrm{~g} \mathrm{~L}^{-1}$ ) in a $15 \mathrm{~mL}$ polypropylene tube, protected from light. The reaction mixture was then left for $60 \mathrm{~min}$ at $40^{\circ} \mathrm{C}$ and vortexed at $15 \mathrm{~min}$ intervals. Excess of $\mathrm{DCl}$ was removed by addition of $0.3 \mathrm{~mL}$ of ammonia solution $\left(300 \mathrm{~g} \mathrm{~L}^{-1}\right)$, vortexing for $1 \mathrm{~min}$ and leaving to react in the dark for $15 \mathrm{~min}$ at room temperature. The sample was extracted twice (duration of each extraction: $5 \mathrm{~min}$ ) with $1 \mathrm{~mL}$ aliquot of diethyl ether. The combined extracts were collected in $2 \mathrm{~mL}$ polypropylene tubes and dried (110 min, room temperature) in a vacuum centrifuge (SpeedVac Concentrator SPD121P, Thermo Fisher Scientific, Marietta, OH, USA). Finally, the residue was re-dissolved in $1 \mathrm{~mL}$ of acetonitrile for injection.

BAs were separated using an Äkta Purifier 10 (GE Healthcare Bio-Sciences, Uppsala, Sweden), equipped with a $20 \mu \mathrm{L}$ loop, a reverse phase $C_{18}$ column (Kromasil $100 \mathrm{~A}, 5 \mu \mathrm{m}, 4.6 \times 250 \mathrm{~mm}$, StepBio, Bologna, Italy) thermostated at $30^{\circ} \mathrm{C}$, with a guard cartridge Kromasil 100-5C18, and a UV detector at $254 \mathrm{~nm}$. BAs were eluted at $0.8 \mathrm{~mL} \mathrm{~min}^{-1}$ with acetonitrile $(\mathrm{A})$ and water $(\mathrm{B})$, using the following gradient: $65 \% \mathrm{~A}(1 \mathrm{~min}), 65-80 \% \mathrm{~A}$ (9 $\mathrm{min}), 80-90 \% \mathrm{~A}$ (2 min), 90-100\% A (4 min), 100\% A (7 min) (Moret, Smela, Populin, \& Conte, 2005). BAs were quantified using calibration curves built up after having analysed standard solutions, containing the following amines dissolved in $0.1 \mathrm{M} \mathrm{HCl}$ at concentrations of 2, 5, 10, and $20 \mu \mathrm{g} \mathrm{mL} \mathrm{m}^{-1}$ : cadaverine, histamine, 2-phenylethylamine, putrescine, spermidine, spermine, tryptamine and tyramine. The following formula was used:

$$
\begin{aligned}
& \text { Concentration of BAs }\left(\mathrm{mg} \mathrm{kg}^{-1} \text { of cheese }\right) \\
& \quad=[(\text { BA peak area/internal standard peak area })-q] / m
\end{aligned}
$$

where $q$ and $m$ are the parameters of the calibration curve for that amine. Prior to HPLC analysis, the standard solutions were derivatised under the same conditions as the acid extracts, except for the concentration of DCl $\left(5 \mathrm{~g} \mathrm{~L}^{-1}\right)$.

\subsection{Determination of $\mathrm{pH}$, water activity, and free amino acids in cheeses}

The value of $\mathrm{pH}$ was determined by direct insertion of a Foodtrode (Hamilton, Bonaduz, Switzerland) electrode. Water activity $\left(a_{\mathrm{w}}\right)$ was determined using the Dew Point Water Activity Meter AquaLab (Mod. 4TE, Decagon Devices, Inc., Pullman, WA, USA), according to the manufacturer's instructions.

Concentration of individual FAAs in cheese was determined as described by Siragusa et al. (2007), with few modifications. In detail, $30 \mathrm{~g}$ of cheese was grated and homogenised (5 min treat-

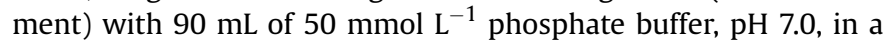
blender. The suspension was kept at $40{ }^{\circ} \mathrm{C}$ for $1 \mathrm{~h}$ under gentle stirring $(150 \mathrm{rpm})$ and centrifuged at $1157 \times \mathrm{g}$ for $30 \mathrm{~min}$ at $4{ }^{\circ} \mathrm{C}$. The supernatant was collected and centrifuged $(1157 \times g, 10 \mathrm{~min}$, $4{ }^{\circ} \mathrm{C}$ ). One millilitre of the supernatant from the second centrifugation was added with $50 \mathrm{mg}$ of cold sulphosalycillic acid (final concentration: $50 \mathrm{mg} \mathrm{mL}^{-1}$ ) and incubated for $1 \mathrm{~h}$ at $4{ }^{\circ} \mathrm{C}$ to precipitate proteins and most of peptides. After centrifugation $(23,000 \times g, 15 \mathrm{~min})$, the extract, containing just FAAs, was filtered (Mini-Uni PrepTM, pore size $0.2 \mu \mathrm{m}$, GE Healthcare Life Science), diluted (if needed) with sodium citrate loading buffer, and injected $(20 \mu \mathrm{L})$ into a Biochrom 30 amino acid analyser (Biochrom Ltd., Cambridge, UK), equipped with a sodium cation-exchange column (20 by $0.46 \mathrm{~cm}$ [inner diameter]). Amino acids were post-column 
Table 1

Parameters used during manufacture and ripening and approximate moisture levels of traditional Apulian or Sicilian cheeses.

\begin{tabular}{|c|c|c|c|c|c|c|c|c|c|c|c|}
\hline Cheese & Code & Location of the dairy factory ${ }^{a}$ & $\begin{array}{l}\text { Type } \\
\text { of milk }\end{array}$ & $\begin{array}{l}\text { Milk thermal } \\
\text { treatment }\end{array}$ & Type of rennet & Type of starter culture ${ }^{c}$ & $\begin{array}{l}\text { Curd thermal treatment } \\
\text { (temperature, time) }\end{array}$ & $\begin{array}{l}\text { Type of } \\
\text { salting }\end{array}$ & $\begin{array}{l}\text { Ripening } \\
\text { time } \\
\text { (days) }\end{array}$ & $\begin{array}{l}\text { Ripening } \\
\text { conditions }^{\mathrm{d}}\end{array}$ & $\begin{array}{l}\text { Moisture } \\
(\%, \mathrm{w} / \mathrm{w})\end{array}$ \\
\hline $\begin{array}{l}\text { Vastedda della Valle del } \\
\text { Belice PDO }\end{array}$ & $\mathrm{C} 1$ & Contessa Entellina (PA), S & $\mathrm{E}$ & None & Lamb, paste & None & Stretching $\left(80^{\circ} \mathrm{C}, 5 \mathrm{~min}\right)$ & Brine & 2 & $\mathrm{nc}$ & 55.0 \\
\hline Caprino di Castel Fiorentino & $\mathrm{C} 2$ & Torremaggiore (FG), A & G & None & Calf, liquid & $\begin{array}{l}\text { Natural milk starter } \\
\text { culture }\end{array}$ & None & Dry & 30 & $10-15, \mathrm{nc}$ & 43.5 \\
\hline Caciocavallo Podolico Dauno & C3 & Torremaggiore (FG), A & C & None & Calf, liquid & $\begin{array}{l}\text { Natural whey starter } \\
\text { culture }\end{array}$ & Stretching $\left(80^{\circ} \mathrm{C}, 5 \mathrm{~min}\right)$ & Brine & 30 & $10-15, \mathrm{nc}$ & 41.9 \\
\hline Fior di Capra & $\mathrm{C} 4$ & Campobello di Licata (AG), S & G & None & $\begin{array}{l}\text { Lamb/kid/plant } \\
\text { paste }\end{array}$ & None & None & Dry & 90 & nc & 41.9 \\
\hline Caprino Girgentano & C5 & Campobello di Licata (AG), S & G & None & Plant (artichoke) & None & None & Dry & 90 & $\mathrm{nc}$ & 40.0 \\
\hline Caprino di Biccari & C6 & Biccari (FG), A & G & Thermisation & $\begin{array}{l}\text { Lamb and calf, } \\
\text { liquid }\end{array}$ & Commercial & None & Dry & 210 & $11-12,70$ & 38.4 \\
\hline Caciocavallo Palermitano & C7 & Godrano (PA), S & C & None & Lamb, paste & None & Stretching $\left(80^{\circ} \mathrm{C}, 5 \mathrm{~min}\right)$ & Brine & 120 & $14-16, \mathrm{nc}$ & 37.0 \\
\hline Ragusano PDO & $\mathrm{C} 8$ & Ragusa (RG), S & C & None & Lamb, paste & None & Stretching $\left(80^{\circ} \mathrm{C}, 5 \mathrm{~min}\right)$ & Brine & 120 & $14-16, \mathrm{nc}$ & 36.9 \\
\hline Caciocavallo Silano PDO & C9 & Putignano (BA), A & C & None & Calf, paste & $\begin{array}{l}\text { Natural whey starter } \\
\text { culture }\end{array}$ & Stretching $\left(85-90^{\circ} \mathrm{C}, 5 \mathrm{~min}\right)$ & Brine & 150 & $12-15,75-80$ & 36.5 \\
\hline Cacioricotta & $\mathrm{C} 10$ & Putignano (BA), A & C & Pasteurisation & Calf, liquid & None & None & Dry & 30 & $20, \mathrm{nc}$ & 36.4 \\
\hline Fiore Sicano & C11 & Castronovo di Sicilia (PA), S & C & None & Kid, paste & None & Stewing $\left(40^{\circ} \mathrm{C}\right)$ & Dry & 60 & $9-13,80-90$ & 36.2 \\
\hline Cacio & $\mathrm{C} 12$ & Casarano (LE), A & $C \& E$ & Pasteurisation & Kid, liquid & Commercial & None & Dry & 60 & $12-14,40$ & 36.0 \\
\hline Vaccino & $\mathrm{C} 13$ & Casarano (LE), A & C & Pasteurisation & Kid, paste & None & None & Brine & 90 & $12-14,40$ & 35.0 \\
\hline Provola dei Nebrodi & $\mathrm{C} 14$ & Mistretta (ME), S & C & Thermisation & Lamb/kid, paste & None & Stretching $\left(80^{\circ} \mathrm{C}, 5 \mathrm{~min}\right)$ & Brine & 30 & $\mathrm{nc}$ & 34.5 \\
\hline Pecorino Foggiano & $\mathrm{C} 15$ & Biccari (FG), A & $\mathrm{E}$ & Thermisation & $\begin{array}{l}\text { Lamb and calf, } \\
\text { liquid }\end{array}$ & Commercial & None & Dry & 120 & $11-12,70$ & 34.2 \\
\hline Canestrato Pugliese PDO & $\mathrm{C} 16$ & Biccari (FG), A & $\mathrm{E}$ & None & Calf, liquid & None & None & Dry & 90 & $11-12,70$ & 34.0 \\
\hline Maiorchino & $\mathrm{C} 17$ & Mistretta (ME), S & $E \& G$ & Thermisation & Lamb/kid, paste & None & Cooking $\left(80^{\circ} \mathrm{C}, 1 \mathrm{~h}\right)$ & Dry & 180 & $\mathrm{nc}$ & 33.3 \\
\hline Pecorino Siciliano PDO & $\mathrm{C} 18$ & Salemi (TP), $\mathrm{S}$ & $\mathrm{E}$ & None & Lamb, paste & None & None & Dry & 120 & $\mathrm{nc}$ & 31.5 \\
\hline Piacentinu Ennese & C19 & Enna (EN), S & $\mathrm{E}$ & None & Lamb, paste & None & None & Dry & 270 & $\mathrm{nc}$ & 29.8 \\
\hline Tuma Persa & $\mathrm{C} 20$ & Castronovo di Sicilia (PA), S & c & Thermisation & Kid, paste & None & None & Dry & 270 & $\mathrm{nc}$ & 27.5 \\
\hline
\end{tabular}

${ }^{a}$ The letter after brackets indicates the region of origin of the cheese: A, Apulia; S, Sicily.

b Types of milk were: $E$ ewe; $C$ goat; $C$ cow.

c Where used, starters were thermophilic, except for those used for Caprino di Biccari and Pecorino Foggiano, which contained both thermophilic (Lactobacillus delbrueckii subsp. bulgaricus, Lactobacillus helveticus, Streptococcus thermophilus) and mesophilic (Lactobacillus casei, Lactococcus lactis subsp. lactis, Lactococcus lactis subsp. cremoris) cultures.

${ }^{\mathrm{d}}$ First number indicates the ripening temperature $\left({ }^{\circ} \mathrm{C}\right)$, the second number indicates the relative humidity (\%) of the ripening cellar; when either ripening temperature or relative humidity were not controlled (nc), cheeses were kept in cool and/or well-ventilated place. 
derivatised with ninhydrin reagent and detected by absorbance at 440 (proline) or 570 (all the other amino acids) nm. FAAs were quantified in the extracts directly through EZChrom Elite version 2.8.3 (Scientific Software Inc., Pleasanton, CA, USA), using amino acid standard solutions containing all the amino acids, each one at concentrations of $31.25,62.50,125$, and $250 \mathrm{mmol} \mathrm{L}^{-1}$.

\subsection{Microbiological analyses and isolation of lactic acid bacteria from cheeses}

Cheeses were processed as follows: $10 \mathrm{~g}$ of cheese were homogenised ( 3 min treatment) with $90 \mathrm{~mL}$ of sodium citrate $\left(20 \mathrm{~g} \mathrm{~L}^{-1}\right)$ solution in a blender. Serial decimal dilutions of homogenates were made in peptone water $\left(\mathrm{NaCl} 8.5 \mathrm{~g} \mathrm{~L}^{-1}\right.$, peptone $\left.10 \mathrm{~g} \mathrm{~L}^{-1}\right)$ and plated onto the following media (Oxoid, Basingstoke, UK) for viable counts: Plate Count (PC) agar for total mesophilic aerobic bacteria at $30{ }^{\circ} \mathrm{C}$ for $48 \mathrm{~h}$; De Man, Rogosa and Sharpe (MRS) agar for presumptive mesophilic and thermophilic lactobacilli at $25^{\circ} \mathrm{C}$ and $42{ }^{\circ} \mathrm{C}$ for $48 \mathrm{~h}$ under anaerobiosis, respectively; M17 agar for mesophilic lactococci and thermophilic streptococci at $25{ }^{\circ} \mathrm{C}$ and $42{ }^{\circ} \mathrm{C}$ for $48 \mathrm{~h}$ under anaerobiosis, respectively; Violet Red Bile Glucose (VRBG) agar for Enterobacteriaceae at $37^{\circ} \mathrm{C}$ for $24 \mathrm{~h}$.

For each medium and condition used for enumerating presumptive lactic acid bacteria, a number of colonies equal to the square root of the total number recorded in plates coming from the highest dilution were randomly selected. Gram-positive, catalasenegative, non-motile rods and cocci isolates were cultivated onto MRS or M17 broth at $25^{\circ} \mathrm{C}$ (mesophilic) or $42^{\circ} \mathrm{C}$ (thermophilic) for $24 \mathrm{~h}$ and re-streaked onto the same agar media. All isolates considered for further analyses were able to acidify the culture medium. Stock cultures were stored at $-80{ }^{\circ} \mathrm{C}$ in $10 \%(\mathrm{v} / \mathrm{v})$ glycerol.

\subsection{Decarboxylase activities of lactic acid bacteria isolated from cheeses}

Lactic acid bacteria isolated from cheeses were screened for their capacity to generate BAs through decarboxylation of precursor amino acids, mainly according to the method described by Bover-Cid and Holzapfel (1999). Isolates were pre-cultured twice in MRS or M17 broth containing the precursor amino acid $\left(1 \mathrm{~g} \mathrm{~L}^{-1}\right)$ and pyridoxal-5-phosphate $\left(0.05 \mathrm{~g} \mathrm{~L}^{-1}\right)$ as an essential cofactor. Decarboxylase medium ( $\mathrm{pH} 5.3$ ) had the following composition $\left(\mathrm{g} \mathrm{L}^{-1}\right)$ : tryptone (5), yeast extract (5), LAB-Lemco (5), sodium chloride (2.5), glucose (0.5), Tween 80 (1), magnesium sulphate (0.2), manganese sulphate (0.05), iron sulphate $(0.04)$, calcium carbonate $(0.1)$, ammonium citrate (2), thiamine (0.01), precursor amino acid (10), dipotassium phosphate (2), pyridoxal-5-phosphate (0.05), bromocresol purple (0.06). Two hundred microlitres of decarboxylase medium were inoculated $(4 \%, v / v)$ with pre-culture into the well of 96-well plate (CytoOne, Starlab s.r.l., Milan, Italy). Decarboxylase medium without precursor amino acid was also inoculated with each isolate (negative control). After incubation at $37{ }^{\circ} \mathrm{C}$ for $96 \mathrm{~h}$, isolates showing colour transition to violet and no colour transition in the negative control were recorded as decarboxylase-positive. Decarboxylase activity was also assessed by inoculating positive isolates (five for each enzyme activity) into MRS or M17 broth supplemented with precursor amino acid $\left(2.5 \mathrm{~g} \mathrm{~L}^{-1}\right.$; Joosten \& Northolt, 1989). Following incubation $\left(25^{\circ} \mathrm{C}\right.$ or $\left.42^{\circ} \mathrm{C}, 48 \mathrm{~h}\right)$, BA concentration was determined as described in Section 2.2.

\subsection{Statistical analyses}

Data (at least three biological replicates) of $\mathrm{pH}, a_{\mathrm{w}}$, concentrations of BAs and FAAs, and cell density of different microbial groups were subjected to pair-comparison of treatment means by Tukey's procedure at $P<0.05$, using the statistical software Statistica 7.0 for Windows (StatSoft Italia srl, Vigonza, Italy). Principal Component Analysis (PCA), using a correlation matrix, was carried out to find the effect of different parameters on the distribution of the cheeses.

\section{Results}

\subsection{Concentration of biogenic amines}

Results concerning biogenic amine contents are presented in Table 2. The sum of cadaverine, histamine, putrescine and tyramine in cheeses was highly variable, with a median value of $137.1 \mathrm{mg} \mathrm{kg}^{-1}$. Pecorino Foggiano (C15) was the only cheese exceeding the concentration of $900 \mathrm{mg} \mathrm{kg}^{-1}$. However, Caciocavallo Silano PDO (C9), Canestrato Pugliese PDO (C16), Caprino di Biccari (C6) and Piacentinu Ennese (C19) cheeses contained high (>500 mg kg-1) total concentrations of cadaverine, histamine, putrescine and tyramine. Conversely, nine cheeses, including Caciocavallo Podolico Dauno (C3), Provola dei Nebrodi (C14) and Vastedda della valle del Belice PDO (C1), showed a low $\left(<100 \mathrm{mg} \mathrm{kg}^{-1}\right.$ ) total concentration.

Overall, the number of Apulian cheeses containing high concentrations of tyramine and putrescine was higher than Sicilian cheeses, whereas the opposite was found for histamine. Tyramine was the only BA detected in all the cheeses, although at extremely variable concentrations (Table 2). The median value for tyramine was $27.15 \mathrm{mg} \mathrm{kg}^{-1}$. Cacio (C12), Canestrato Pugliese PDO (C16) and Pecorino Foggiano (C15) were characterised by high concentrations (273-305 mg kg-1) of tyramine. Histamine median value was $31.5 \mathrm{mg} \mathrm{kg}^{-1}$. It was not detected in Caciocavallo Podolico Dauno (C3) and Caprino di Castel Fiorentino (C2) cheeses. The median value for putrescine was $15.7 \mathrm{mg} \mathrm{kg}^{-1}$. Pecorino Foggiano (C15), Caprino di Biccari (C6), Canestrato Pugliese PDO (C16) and Piacentinu Ennese (C19) cheeses contained largely more than $100 \mathrm{mg}$ of putrescine per kg. Caciocavallo Podolico Dauno (C3) was the only cheese not containing a detectable concentration of putrescine. The median value for cadaverine was $4.15 \mathrm{mg} \mathrm{kg}^{-1}$. Canestrato Pugliese PDO (C16), Pecorino Foggiano (C15) and Cacio (C12) cheeses contained cadaverine at concentrations higher than $100 \mathrm{mg} \mathrm{kg}^{-1}$. Conversely, cadaverine was not detected in Caciocavallo Palermitano (C7), Caprino di Castel Fiorentino (C2) and Tuma Persa (C20) cheeses. 2-phenylethylamine varied from 0 to ca. $145 \mathrm{mg} \mathrm{kg}$ (Table 2), with a median value of $3.3 \mathrm{mg} \mathrm{kg}^{-1}$. Caprino di Biccari (C6), Cacio (C12) and Maiorchino (C17) showed the highest concentration of 2-phenylethylamine.

Considering $100 \mathrm{mg} \mathrm{kg}^{-1}$ as the limit of concentration of each individual BA in cheeses, histamine, tyramine, and putrescine exceeded this limit in the highest number of cheeses (seven, five, and four, respectively), more than for cadaverine and 2phenylethylamine. Tryptamine and, especially, spermidine and spermine were either not detected or present at concentration lower than $100 \mathrm{mg} \mathrm{kg}^{-1}$. Five cheeses (Cacio, Canestrato Pugliese PDO, Caprino di Biccari, Pecorino Foggiano, and Piacentinu Ennese) showed concentration higher than $100 \mathrm{mg} \mathrm{kg}^{-1}$ not only for tyramine but also for other two or three BAs. Five cheeses (Caciocavallo Palermitano, Caciocavallo Silano PDO, Fiore Sicano, Pecorino Siciliano PDO, and Tuma Persa) were characterised by high concentration of only histamine. The remaining cheeses, including Apulian and Sicilian types, contained BAs at individual concentration lower than $100 \mathrm{mg} \mathrm{kg}^{-1}$ (Table 2).

\section{2. $p H$, water activity and concentration of free amino acids}

The values of $\mathrm{pH}$ and $a_{\mathrm{w}}$ varied from approximately 4.93 (Canestrato Pugliese PDO, C16) to ca. 5.71 (Provola dei Nebrodi, 
Table 2

Concentration of biogenic amines in traditional Apulian or Sicilian cheeses.

\begin{tabular}{|c|c|c|c|c|c|c|c|c|c|}
\hline Cheese $^{\mathrm{a}}$ & Cadaverine & Histamine & 2-Phenylethylamine & Putrescine & Spermidine & Spermine & Tryptamine & Tyramine & Total $^{\mathrm{b}}$ \\
\hline $\mathrm{C} 1$ & $1(0.1)$ & $5.7(0.4)$ & $0.5(0.1)$ & $1.1(0.1)$ & $0.3(0.2)$ & $1.1(0.9)$ & $1.4(0.2)$ & $5.9(0.1)$ & 13.7 \\
\hline $\mathrm{C} 2$ & nd & nd & nd & $9(3)$ & nd & $4.7(0.3)$ & nd & $25(3)$ & 34 \\
\hline C3 & $1.4(0.2)$ & nd & nd & nd & nd & $13.6(0.4)$ & nd & 7 (1) & 8.4 \\
\hline C4 & $0.3(0.0)$ & $18(5)$ & nd & $15.4(0.6)$ & nd & nd & $0.8(0.2)$ & $29.3(0.2)$ & 63 \\
\hline C5 & $0.9(0.0)$ & $89(9)$ & $4(0.0)$ & $6.2(0.7)$ & nd & nd & $0.4(0.1)$ & $1.7(0.1)$ & 97.8 \\
\hline C6 & $27(2)$ & $44(3)$ & $145(18)$ & $298(17)$ & $5(3)$ & nd & $73(12)$ & $227(26)$ & 596 \\
\hline C7 & nd & $149(3)$ & nd & $12(4)$ & $13(5)$ & nd & $4(1)$ & $4(3)$ & 165 \\
\hline C8 & $2.9(0.0)$ & $54.8(0.3)$ & $4.5(0.0)$ & $7.6(0.3)$ & nd & nd & nd & $23.9(0.1)$ & 89.2 \\
\hline C9 & $17(0.7)$ & $435(35)$ & nd & $37(5)$ & nd & nd & $6(1)$ & $33(4)$ & 522 \\
\hline C10 & $18(5)$ & $19(5)$ & nd & $14(4)$ & $5(2)$ & $10(0.5)$ & nd & $13(4)$ & 64 \\
\hline C11 & $32(1)$ & $155(22)$ & $2.6(0.5)$ & $16(3)$ & nd & nd & $53(16)$ & $32(5)$ & 235 \\
\hline C12 & $111(23)$ & $17(3)$ & $143(16)$ & $53(9)$ & $\mathrm{nd}^{\mathrm{b}}$ & nd & $18(2)$ & 305 (55) & 486 \\
\hline C13 & $28(1)$ & $14.9(0.3)$ & nd & $62(6)$ & nd & $15(3)$ & nd & $4.3(0.6)$ & 109.2 \\
\hline $\mathrm{C} 14$ & $0.4(0.0)$ & $1(0.0)$ & $0.1(0.0)$ & $0.75(0.03)$ & $0.10(0.0)$ & nd & $0.1(0.0)$ & $1.0(0.1)$ & 3.2 \\
\hline C15 & $129(27)$ & $253(30)$ & $25(11)$ & $594(11)$ & nd & nd & nd & $303(26)$ & 1279 \\
\hline C16 & 199 (19) & $3.9(0.4)$ & $46(3)$ & 208 (19) & $4(2)$ & nd & nd & $273(28)$ & 683.9 \\
\hline $\mathrm{C} 17$ & $1.3(0.1)$ & $2.0(0.7)$ & $82(5)$ & $5(0.0)$ & $3.5(4.1)$ & nd & $1.9(0.2)$ & $61(18)$ & 69.3 \\
\hline C18 & $5.4(0.3)$ & $219(11)$ & $9(1)$ & $60(3)$ & $2(0.0)$ & nd & $2.8(0.4)$ & $86(17)$ & 370.4 \\
\hline C19 & $9.5(1)$ & $243(6)$ & $28.5(1)$ & $204(1)$ & $10(2)$ & nd & $6(1)$ & $134(9)$ & 590.5 \\
\hline $\mathrm{C} 20$ & nd & $250(16)$ & $4(0.5)$ & $23(3)$ & nd & nd & $2.3(1.4)$ & $14(0.1)$ & 287 \\
\hline
\end{tabular}

${ }^{a}$ Values (in $\mathrm{mg} \mathrm{kg}^{-1}$ ) are means with standard deviation in parentheses; nd, not detected. For cheese codes C1-C20, see Table 1.

b Sum of cadaverine, histamine, putrescine, and tyramine.

C14), and from approximately 0.73 (Cacioricotta, C10) to approximately 0.99 (Vastedda della valle del Belice PDO, C1), respectively (Table 3). The median values for $\mathrm{pH}$ and $a_{\mathrm{w}}$ were 5.40 and 0.93 , respectively. Most of the cheeses had an intermediate acidity $(4.5<\mathrm{pH}<5.5)$, with the exceptions of Cacio (C12), Ragusano PDO (C8), Pecorino Siciliano PDO (C18), Piacentinu Ennese (C19), Provola dei Nebrodi (C14), and Vastedda della valle del Belice PDO (C1), which showed higher values of $\mathrm{pH}$. Except for Cacioricotta (C10), Canestrato Pugliese PDO (C16), Pecorino Foggiano (C15) and Piacentinu Ennese (C19) cheeses, which showed values of $a_{\mathrm{w}}$ lower than 0.90 , all the other cheeses had an intermediate to high value of $a_{\mathrm{w}}$.

The concentration of total FAAs ranged from 622 (Cacioricotta) to 12,779 (Tuma Persa) $\mathrm{mg} \mathrm{kg}^{-1}$, with a median value of $4524.5 \mathrm{mg} \mathrm{kg}^{-1}$. The total concentration of FAA precursors of BAs varied in the interval $216-4275 \mathrm{mg} \mathrm{kg}^{-1}$, the median value being $1479.5 \mathrm{mg} \mathrm{kg}^{-1}$. Tuma Persa was by far the cheese characterised by the highest concentration of total FAAs potentially precursors of BAs, followed by Caciocavallo Silano PDO (C9), Caprino di Biccari (C6) and Piacentinu Ennese (C19) (approximately 2500-2900 mg kg-1) (Table 3). Ragusano PDO, Cacioricotta and Provola dei Nebrodi cheeses showed the lowest concentration of total precursor FAAs (approximately 200-300 $\mathrm{mg} \mathrm{kg}^{-1}$ ), whereas the other cheeses had intermediate values. Among individual FAAs, lysine and arginine were present at the highest (452 $\mathrm{mg} \mathrm{kg}^{-1}$ ) and the lowest (57 $\mathrm{mg} \mathrm{kg}^{-1}$ ) median values, respectively. Tyrosine, phenylalanine, and ornithine were found at highest concentration in Tuma Persa cheese. Histidine and arginine showed the highest concentrations in Caciocavallo Silano PDO (Table 3).

\subsection{Microbiological analyses and free amino acid-decarboxylase activities of presumptive lactic acid bacteria}

When detected, Enterobacteriaceae was the microbial group found at the lowest cell density. Enterobacteriaceae ranged from approximately $2.0 \mathrm{log} \mathrm{cfu} \mathrm{g}^{-1}$ (Fiore Sicano, C11) to approximately

Table 3

$\mathrm{pH}$, water activity and concentration $\left(\mathrm{mg} \mathrm{kg}^{-1}\right)$ of total and precursor free amino acids of traditional Apulian or Sicilian cheeses. ${ }^{\text {a }}$

\begin{tabular}{|c|c|c|c|c|c|c|c|c|c|c|c|}
\hline \multirow[t]{2}{*}{ Cheese } & \multirow[t]{2}{*}{$\mathrm{pH}$} & \multirow[t]{2}{*}{ Water activity } & \multicolumn{9}{|c|}{ Free amino acids } \\
\hline & & & Total & Tyrosine & Phenylalanine & Histidine & Tryptophan & Ornithine & Lysine & Arginine & Precursor \\
\hline $\mathrm{C} 1$ & $5.57(0.02)$ & $0.99(0.00)$ & 1161 & $31(2)$ & $110(7)$ & $15(2)$ & $19(2)$ & $125(7)$ & $109(7)$ & $8(2)$ & 417 \\
\hline $\mathrm{C} 2$ & $5.31(0.02)$ & $0.90(0.01)$ & 3230 & $142(7)$ & $264(12)$ & $68(5)$ & $168(7)$ & $36(3)$ & 275 (13) & $82(5)$ & 1035 \\
\hline $\mathrm{C} 3$ & $4.95(0.03)$ & $0.90(0.02)$ & 2871 & $109(7)$ & $210(10)$ & $94(7)$ & $117(10)$ & $10(4)$ & $338(18)$ & $262(15)$ & 1140 \\
\hline C4 & $5.30(0.01)$ & $0.93(0.00)$ & 3901 & $164(14)$ & $507(45)$ & $69(7)$ & $158(17)$ & $392(40)$ & $429(40)$ & $31(4)$ & 1750 \\
\hline C5 & $5.29(0.00)$ & $0.94(0.01)$ & 5618 & $282(20)$ & $505(31)$ & $108(7)$ & $164(11)$ & $182(10)$ & $521(32)$ & $251(16)$ & 2013 \\
\hline C6 & $4.99(0.01)$ & $0.94(0.00)$ & 9074 & $107(8)$ & $750(53)$ & $222(15)$ & $301(24)$ & $24(3)$ & $1170(88)$ & $173(15)$ & 2747 \\
\hline $\mathrm{C} 7$ & $5.44(0.00)$ & $0.97(0.00)$ & 2076 & $76(8)$ & $139(11)$ & $45(6)$ & $59(5)$ & $22(3)$ & $201(17)$ & $64(6)$ & 606 \\
\hline $\mathrm{C} 8$ & $5.51(0.01)$ & $0.97(0.01)$ & 779 & $23(5)$ & 88 (10) & $19(2)$ & $25(4)$ & $39(2)$ & $83(5)$ & nd & 277 \\
\hline C9 & $5.04(0.00)$ & $0.93(0.01)$ & 8708 & $241(16)$ & $441(30)$ & $380(26)$ & $75(6)$ & $10(4)$ & $1016(75)$ & $428(31)$ & 2591 \\
\hline C10 & $5.25(0.02)$ & $0.73(0.01)$ & 622 & $15(2)$ & $57(18)$ & $8(3)$ & $44(5)$ & $6(1)$ & $64(4)$ & $22(2)$ & 216 \\
\hline C11 & $5.46(0.00)$ & $0.96(0.00)$ & 1259 & $26(2)$ & $175(8)$ & $68(4)$ & $36(2)$ & $106(6)$ & $92(4)$ & $18(2)$ & 521 \\
\hline C12 & $5.58(0.01)$ & $0.95(0.01)$ & 4442 & $68(3)$ & $342(14)$ & $112(8)$ & $194(10)$ & $171(7)$ & 476 (19) & $65(3)$ & 1428 \\
\hline $\mathrm{C} 13$ & $5.37(0.03)$ & $0.97(0.02)$ & 4607 & $78(8)$ & $358(33)$ & $128(13)$ & $240(21)$ & $177(18)$ & $483(44)$ & $67(8)$ & 1531 \\
\hline C14 & $5.71(0.01)$ & $0.97(0.00)$ & 762 & $46(2)$ & $64(3)$ & $14(2)$ & $63(4)$ & $47(2)$ & $59(3)$ & $20(1)$ & 313 \\
\hline C15 & $5.14(0.01)$ & $0.89(0.01)$ & 4629 & $67(5)$ & $398(30)$ & $64(5)$ & $163(12)$ & $17(2)$ & $549(42)$ & $49(4)$ & 1307 \\
\hline C16 & $4.93(0.02)$ & $0.84(0.02)$ & 5126 & $106(11)$ & $432(36)$ & $99(12)$ & $271(26)$ & $126(1)$ & $415(35)$ & $131(13)$ & 1580 \\
\hline C17 & $5.46(0.00)$ & $0.93(0.01)$ & 78,88 & $46(4)$ & $586(46)$ & $137(11)$ & $203(18)$ & $545(48)$ & $817(75)$ & nd & 2334 \\
\hline C18 & $5.56(0.00)$ & $0.91(0.00)$ & 8332 & $153(7)$ & 419 (19) & $89(5)$ & $117(6)$ & 254 (11) & $1086(55)$ & nd & 2118 \\
\hline C19 & $5.51(0.01)$ & $0.89(0.02)$ & 11,569 & $167(10)$ & 830 (49) & $127(6)$ & $182(11)$ & $106(6)$ & $1397(80)$ & $139(8)$ & 2948 \\
\hline $\mathrm{C} 20$ & $5.50(0.00)$ & $0.90(0.01)$ & 12,779 & 377 (35) & $1108(91)$ & $264(25)$ & $272(26)$ & $682(66)$ & $1522(147)$ & $50(5)$ & 4275 \\
\hline
\end{tabular}

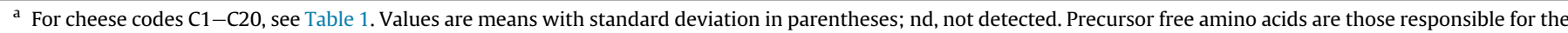
synthesis of biogenic amines. 
Table 4

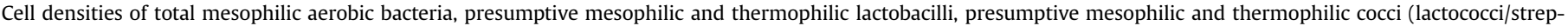
tococci), and Enterobacteriaceae in traditional Apulian or Sicilian cheeses.

\begin{tabular}{|c|c|c|c|c|c|c|}
\hline Cheese $^{\mathrm{a}}$ & $\begin{array}{l}\text { Total mesophilic } \\
\text { aerobic bacteria }\end{array}$ & Mesophilic lactobacilli & Thermophilic lactobacilli & Mesophilic lactococci & Thermophilic streptococci & Enterobacteriaceae \\
\hline $\mathrm{C} 1$ & $8.3(0.4)$ & $7.5(0.5)$ & $7.8(0.4)$ & $8.5(0.5)$ & $8.7(0.4)$ & $2.8(0.2)$ \\
\hline $\mathrm{C} 2$ & $4.9(0.3)$ & $8.7(0.1)$ & $7.6(0.0)$ & $8.9(0.1)$ & $8.7(0.2)$ & $4.7(0.3)$ \\
\hline $\mathrm{C} 3$ & $4.2(0.2)$ & $6.4(0.1)$ & $5.8(0.8)$ & $7.3(0.0)$ & $8.6(0.1)$ & $<1.0$ \\
\hline C4 & $7.9(0.4)$ & $7.6(0.0)$ & $4.9(0.1)$ & $7.5(0.1)$ & $5.0(0.1)$ & $<1.0$ \\
\hline C5 & $6.4(0.1)$ & $6.9(0.1)$ & $6.1(0.0)$ & $6.8(0.2)$ & $6.8(0.3)$ & $<1.0$ \\
\hline C6 & $7.2(0.1)$ & $7.2(0.1)$ & $7.2(0.2)$ & $7.0(0.3)$ & $6.6(0.1)$ & $<1.0$ \\
\hline$C 7$ & $6.7(0.3)$ & $6.6(0.4)$ & $5.8(0.2)$ & $6.4(0.4)$ & $5.6(0.3)$ & $2.5(0.2)$ \\
\hline $\mathrm{C} 8$ & $8.8(0.2)$ & $7.0(0.1)$ & $7.2(0.3)$ & $7.2(0.3)$ & $7.5(0.2)$ & $<1.0$ \\
\hline C9 & $6.4(0.3)$ & $6.7(0.2)$ & $6.7(0.0)$ & $7.0(0.1)$ & $6.7(0.1)$ & $<1.0$ \\
\hline $\mathrm{C} 10$ & $7.0(0.2)$ & $7.0(0.2)$ & $6.9(0.4)$ & $7.1(0.2)$ & $7.0(0.1)$ & $4.3(0.5)$ \\
\hline C11 & $8.3(0.1)$ & $8.0(0.6)$ & $5.9(0.1)$ & $8.2(0.2)$ & $5.5(0.2)$ & $2.0(0.4)$ \\
\hline C12 & $7.6(0.1)$ & $7.6(0.2)$ & $7.4(0.2)$ & $7.6(0.3)$ & $7.3(0.2)$ & $4.0(0.1)$ \\
\hline C13 & $8.0(0.5)$ & $7.9(0.3)$ & $8.1(0.1)$ & $8.0(0.1)$ & $7.7(0.3)$ & $3.4(0.4)$ \\
\hline C14 & $7.8(0.1)$ & $7.8(0.2)$ & $6.7(0.3)$ & $6.7(0.2)$ & $6.6(0.0)$ & $<1.0$ \\
\hline C15 & $7.4(0.2)$ & $7.6(0.2)$ & $7.5(0.3)$ & $7.6(0.1)$ & $7.2(0.1)$ & $2.6(0.2)$ \\
\hline C16 & $8.4(0.2)$ & $7.7(0.1)$ & $7.5(0.0)$ & $8.8(0.2)$ & $8.3(0.3)$ & $4.3(0.2)$ \\
\hline C17 & $7.7(0.0)$ & $7.2(0.2)$ & $7.0(0.0)$ & $5.4(0.2)$ & $5.4(0.3)$ & $<1.0$ \\
\hline C18 & $5.8(0.2)$ & $5.2(0.2)$ & $5.0(0.3)$ & $5.4(0.1)$ & $5.2(0.2)$ & $<1.0$ \\
\hline C19 & $8.1(0.1)$ & $6.9(0.1)$ & $6.2(0.5)$ & $6.8(0.2)$ & $6.1(0.3)$ & $<1.0$ \\
\hline $\mathrm{C} 20$ & $6.4(0.1)$ & $6.3(0.3)$ & $3.9(0.2)$ & $6.2(0.2)$ & $4.5(0.1)$ & $<1.0$ \\
\hline
\end{tabular}

${ }^{\text {a }}$ For cheese codes $\mathrm{C} 1-\mathrm{C} 20$, see Table 1 ; values $\left(\log \mathrm{cfu}^{-1}\right)$ are means with standard deviation in parentheses.

$4.7 \log \mathrm{cfu} \mathrm{g}^{-1}$ (Caprino di Castel Fiorentino, C2) (Table 4). Total aerobic mesophilic bacteria varied from approximately $4.2 \log _{\text {cfu g }}{ }^{-1}$ (Caciocavallo Podolico Dauno, C3) to approximately $8.8 \mathrm{log} \mathrm{cfu} \mathrm{g}^{-1}$ (Ragusano PDO, C8), with a median value of $7.5 \log \mathrm{cfu} \mathrm{g}^{-1}$. The median value for presumptive mesophilic lactobacilli was $7.2 \log \mathrm{cfu} \mathrm{g}^{-1}$, with Pecorino Siciliano PDO (C18) and Caprino di Castel Fiorentino (C2) cheeses showing the lowest (approximately $5.2 \mathrm{log} \mathrm{cfu} \mathrm{g}^{-1}$ ) and the highest (approximately $8.7 \log \mathrm{cfu} \mathrm{g}^{-1}$ ) value, respectively. Presumptive thermophilic lactobacilli varied from approximately $3.9 \mathrm{log} \mathrm{cfu} \mathrm{g}^{-1}$ (Tuma Persa, C20) to approximately $8.1 \mathrm{log} \mathrm{cfu} \mathrm{g}^{-1}$ (Vaccino, C13), the median value being $6.8 \mathrm{log} \mathrm{cfu} \mathrm{g}^{-1}$. Cell density of presumptive mesophilic lactococci ranged from approximately $5.4 \mathrm{log} \mathrm{cfu} \mathrm{g}^{-1}$ (Maiorchino C17 and Pecorino Siciliano PDO) to approximately $8.9 \log \mathrm{cfu} \mathrm{g}^{-1}$ (Caprino di Castel Fiorentino), with a median value of $7.15 \log$ cfu g $^{-1}$. Presumptive thermophilic streptococci varied from approximately $4.5 \mathrm{log} \mathrm{cfu} \mathrm{g}^{-1}$ (Tuma Persa) to approximately 8.7 $\log \mathrm{cfu} \mathrm{g}^{-1}$ (Caprino di Castel Fiorentino and Vastedda della valle del Belice PDO, C1), with a median value of $6.75 \log \mathrm{cfu} \mathrm{g}^{-1}$.

A number of Gram-positive, catalase-negative, non-motile cocci and rods, able to acidify M17 or MRS broth, were isolated. From each cheese, 15-47 presumptive lactic acid bacteria were considered. All the isolates were assayed for those decarboxylase activities leading to the formation of the four BAs (cadaverine, histamine, putrescine, and tyramine) that exceeded the limit of $100 \mathrm{mg} \mathrm{kg}^{-1}$ in at least three cheeses. Arginine-decarboxylase was not considered, since arginine first has to be converted either into ornithine or agmatine, which are direct precursors for putrescine. Tyrosine decarboxylase was the most frequent enzyme activity within isolates, regardless of the group (mesophilic/thermophilic lactobacilli, mesophilic lactococci, and thermophilic streptococci) of lactic acid bacteria (data not shown). Indeed, isolates showing this enzyme activity were found in 16 out of 20 cheeses. The percentage of lactic acid bacteria showing tyrosine decarboxylase activity was 24 or higher for 8 cheeses (Cacio, Caciocavallo Palermitano, Caciocavallo Silano PDO, Canestrato Pugliese PDO, Caprino di Biccari, Maiorchino, Pecorino Foggiano and Pecorino Siciliano PDO). No isolates able to decarboxylate tyrosine were found in Ragusano PDO, Fiore Sicano, Piacentinu Ennese, and Vaccino cheeses. Isolates with histidine decarboxylase activity were found in 15 out of 20 cheeses and the percentage was high (38\%), especially for lactic acid bacteria from Caciocavallo Silano PDO cheese. None of the lactic acid bacteria isolated from Caciocavallo Podolico Dauno, Caprino di Castel Fiorentino, Caprino Girgentano, Maiorchino, and Provola dei Nebrodi cheeses showed histidine decarboxylase activity (data not shown). Cacio, Caciocavallo Podolico Dauno, Cacioricotta, Caprino di Biccari, Caprino Girgentano, Fior di Capra, Pecorino Foggiano, and Vaccino cheeses harboured isolates with lysine decarboxylase activity. Ornithine decarboxylase-positive isolates were found in Cacio, Cacioricotta, Caprino di Biccari, Caprino di Castel Fiorentino, Pecorino Foggiano, Vaccino, and Vastedda della valle del Belice PDO (data not shown). Decarboxylase activities of 20 isolates were confirmed by HPLC analyses (data not shown).

\subsection{Correlations between concentrations of biogenic amines and different cheese parameters}

PCA was carried out to formulate hypotheses regarding the concentration of the most frequent BAs (cadaverine, histamine, putrescine, and tyramine), as possibly influenced by different cheese parameters. A preliminary PCA revealed that type of milk, thermal treatment of milk/curd, $a_{\mathrm{w}}$, and cell densities of Enterobacteriaceae were not correlated with the concentration of the above mentioned BAs (data not shown). Another PCA was carried out considering the remaining parameters: use of starter culture, type of rennet, cell densities of presumptive lactic acid bacteria and total mesophilic bacteria, concentration of precursor amino acids, percentages of histidine, lysine, ornithine, and tyrosine decarboxylase-positive isolates, time of ripening and $\mathrm{pH}$ of the cheese. Two principal components (PC1 and PC2) explained almost $53 \%$ of the total variance of the data (Fig. 1). The negative segment of PC1 was related to the cell density of presumptive mesophilic and thermophilic lactobacilli, of mesophilic lactococci, and of thermophilic streptococci, whereas its positive segment was related to the concentration of tyrosine and time of ripening. Concentration of putrescine and tyramine showed the highest loads for PC2. Concentration of lysine and time of cheese ripening showed the highest correlation $(r=\sim 0.87)$, followed by cadaverine and tyramine $(r=\sim 0.83$ ), and by histamine and percentage of histidine decarboxylase-positive bacteria $(r=\sim 0.81)$. Histamine 


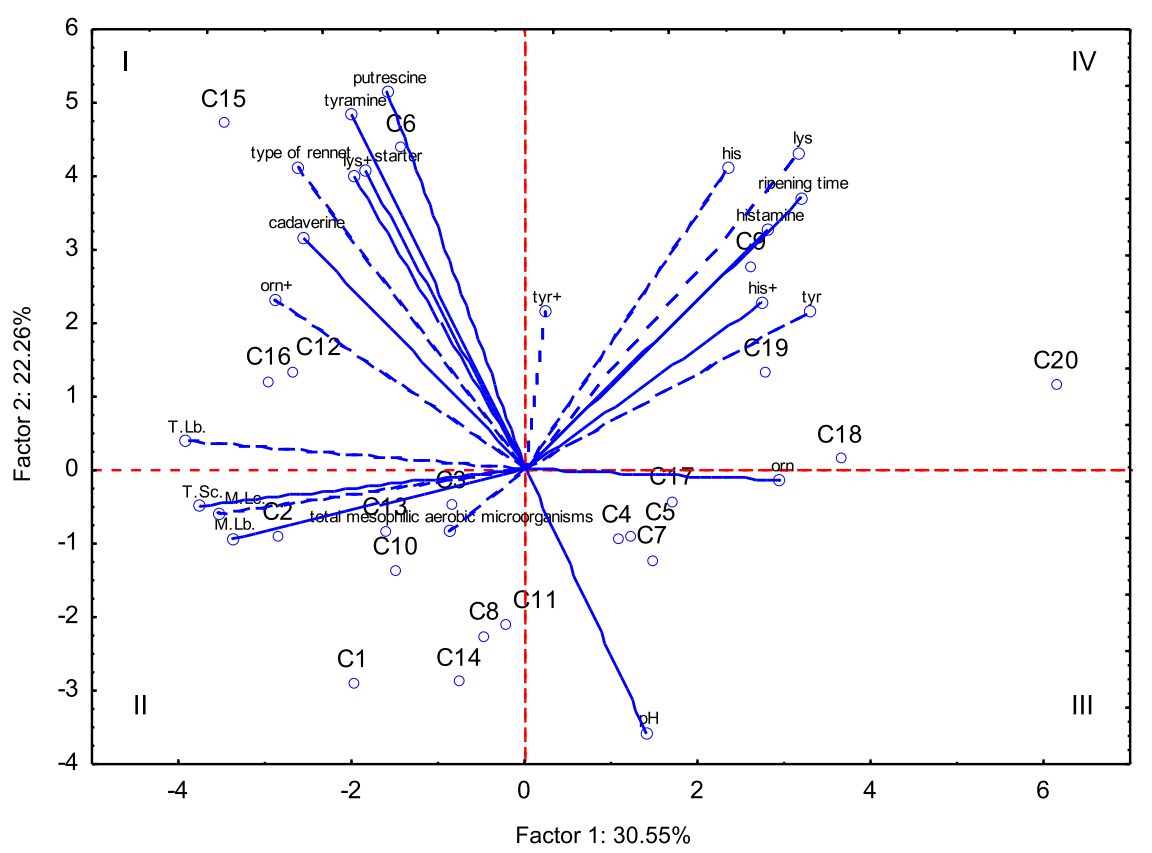

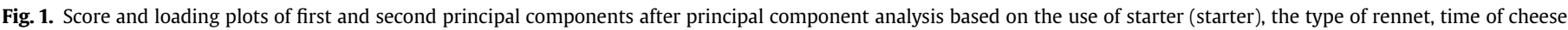

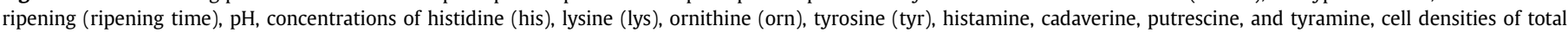

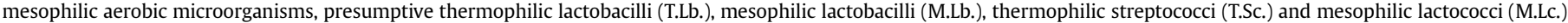

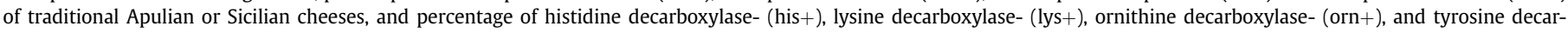
boxylase- (tyr+) positive lactic acid bacteria isolated from the cheeses. Each cheese is indicated by the alphanumeric code (C1-C20) assigned in Table 1.

also showed relatively high positive correlations with the concentration of histidine $(r=\sim 0.61)$ and time of ripening $(r=\sim 0.54)$. Putrescine was positively correlated with tyramine $(r=0.76)$ and type of rennet $(r=0.71)$. Lower positive correlations were found between each single BA and use of starter $(0.14<r<0.44)$, as well as between cadaverine and cell density of mesophilic lactococci $(r=0.43)$, and cadaverine and type of rennet $(r=0.42)$. The value of $\mathrm{pH}$ and concentration of cadaverine, putrescine, and tyramine were negatively correlated, being the value of $r$ approximately $-0.39,-0.40$, and -0.29 , respectively.

Canestrato Pugliese PDO (C16), Cacio (C12), Caprino di Biccari (C6), and Pecorino Foggiano (C15) cheeses were grouped in the I quadrant mainly because of their high concentration of tyramine and cell density of presumptive lactic acid bacteria. Caciocavallo Silano PDO (C9), Pecorino Siciliano PDO (C18), Piacentinu Ennese (C19), and Tuma Persa (C20) cheeses fell in the IV quadrant, because they were characterised by high concentration of histamine and tyrosine. All the other cheeses were located in the remaining quadrants (II and III) of the plane. These cheeses were characterised by low concentration of BAs, except for Caciocavallo Palermitano (C7) and Fiore Sicano (C11), which contained more than $100 \mathrm{mg}$ of histamine per $\mathrm{kg}$ (Fig. 1).

\section{Discussion}

Consumers' preference for traditional cheeses is currently increasing mainly for two reasons: (i) industrial cheeses are perceived as having "boring" flavour and taste; (ii) consumers prefer the so-called "short distribution chain", probably the main distribution channel for these products. Because the majority of traditional cheeses are subjected to looser controls than industrial ones, their content in BAs may represent a potential safety issue (Ten Brink, Damink, Joosten, \& Huis in't Veld, 1990).

In this study, traditional Apulian or Sicilian cheeses were analysed for the concentration of eight BAs, and a number of technological, biochemical and microbiological parameters. Presumptive lactic acid bacteria, isolated from these cheeses, were assayed for their capacity to generate BAs through decarboxylation of precursor amino acids.

In this study, short-ripened ( $\leq 30 \mathrm{~d}$ ) cheeses did not show significant BA concentrations. No cheeses showing toxic concentrations of at least one BA were ripened for less than 60 days. PCA showed that BA concentrations and time of ripening were not correlated, except for histamine. Overall, the amount of BAs increases as the time of ripening increases (Bunková et al., 2010; Novella-Rodrìguez, Veciana-Noguès, Trujillo-Mesa, \& Vidal-Carou, 2002; Ordóñez, Ibanez, Torre, \& Barcina, 1997; Schneller, Good, \& Jenny, 1997; Spizzirri et al., 2013). Previous studies (Mayer, Fiechter, \& Fischer, 2010; Novella-Rodrìguez, Veciana-Noguès, IzquierdoPulido, \& Vidal-Carou, 2003) showed that cheeses having similar time of ripening markedly differed from each other in terms of BA concentration, and this was attributed mostly to the extent of ripening. Accordingly, in this study, some cheeses (Ragusano PDO, Fior di Capra, Vaccino) showed low BA concentration, although they were ripened for $90-120 \mathrm{~d}$. Further, time of ripening was highly and positively correlated with concentration of lysine, which may indicate a high extent of proteolysis during ripening.

Within our set of data, histamine was the only BA positively correlated with the corresponding precursor amino acid. Previous studies reported significant positive correlations between BAs and corresponding precursor amino acids (Kebary, El-Sonbaty, \& Badawi, 1999; Pinho et al., 2004). On the contrary, no significant correlation was found between tyramine and tyrosine in traditional Turkish Civil cheese (Yildiz et al., 2010). These apparently conflicting results may be explained by the fact that availability of precursor amino acids is not a sufficient prerequisite for BA production, rather than needing the concurrent presence of decarboxylase-positive bacteria is. In this regard, we found a high positive correlation between histamine and percentage of histamine decarboxylase-positive bacteria (Fig. 1). This was in 
substantial agreement with a previous study (Schirone et al., 2013). Surprisingly we found that concentration of tyramine, concentration of tyrosine and percentage of tyrosine decarboxylase-positive isolates were not associated (Fig. 1). This could be explained by the ability of some bacterial tyrosine decarboxylases to generate, besides tyramine, 2-phenylethylamine from phenylalanine (Marcobal, De Las Rivas, Landete, Tabera, \& Muñoz, 2012). We found that cadaverine was positively correlated with cell density of mesophilic lactococci. Pintado et al. (2008) reported a positive correlation between lactococci and tyramine. Among mesophilic lactococci, some isolates belonging either to Lactococcus sp. or Leuconostoc sp. were capable of producing cadaverine upon lysine decarboxylation (Marino, Maifreni, Bartolomeoli, \& Rondinini, 2008).

Although positive correlation was found between type of rennet and putrescine, based on the results of this study no hypotheses can be done about the role of rennet on BA formation. Indeed, rennet parameters, such as microbiological quality, proteolytic activity, and BA concentration, which would presumably affect BA concentration in cheeses, were not evaluated in this study.

Within our data, PCA showed $\mathrm{pH}$ as negatively correlated to the concentrations of tyramine, putrescine, and cadaverine (Fig. 1). Previously, it was shown that low pH (e.g., 4.0-5.5) favours generation of BAs, because FAA decarboxylation is part of microbial cell response to acid stress, which allows the consumption of intracellular protons (Andiç, Gençcelep, Tunçtürk, \& Köse, 2010; Fernández et al., 2007; Marcobal, Martin-Alvarez, Moreno-Arribas, \& Muñoz, 2006).

We found that starter preparation may affect concentration of BAs. This should not be regarded as surprising, taking into account that some lactic acid bacteria (e.g., Lactobacillus delbrueckii, Lactobacillus helveticus, Streptococcus thermophilus) used as dairy starters showed the capacity to decarboxylate amino acids precursors of BAs (Burdychova \& Komprda, 2007; Marino et al., 2008; RoigSagués, Molina, \& Hernández-Herrero, 2002). Previous studies provided contradictory results about the role of starters in the production of BAs in cheeses (Marino et al., 2008; Martuscelli et al., 2005). Commercial starters, such as those used for Cacio, Pecorino Foggiano, and Caprino di Biccari, desirably should not contain decarboxylate-positive bacteria. However this feature is often overlooked. Natural starter preparations, such as those used for Caciocavallo Podolico Dauno, Caciocavallo Silano PDO, and Caprino di Castel Fiorentino cheeses, likely harbour bacteria capable of producing BAs.

In this study, Cacio, Canestrato Pugliese PDO, Caprino di Biccari, Pecorino Foggiano, and Piacentinu Ennese cheeses contained at least three BAs at potentially toxic concentrations. Caciocavallo Palermitano, Caciocavallo Silano PDO, Fiore Sicano, Pecorino Siciliano PDO and Tuma Persa cheeses showed food safety issue related to the high concentration of histamine.

\section{Conclusions}

This study considered all the parameters that potentially affect the concentrations of the four most common BAs in cheese. Unambiguous and ever-valid relations among certain parameters and BAs are difficult to determine. We found that even the time of ripening, always being reported as a key-parameter, cannot be accepted in all cases. This is because BAs are the result of combined and varied factors.

\section{Acknowledgements}

This work was supported by Ministero dell'Istruzione, dell'Università e della Ricerca (Rome, Italy; Futuro in Ricerca 2010, code RBFR108RDK), and by Ministero dell'Istruzione, dell'Università e della Ricerca, Ministero dello Sviluppo Economico and Fondo Europeo di Sviluppo Regionale (PON02_00186_3417037, project PROINNO_BIT).

\section{References}

Andiç, S., Gençcelep, H., Tunçtürk, Y., \& Köse, S. (2010). The effect of storage temperatures and packaging methods on properties of Motal cheese. Journal of Dairy Science, 93, 849-859.

Beresford, T., \& Williams, A. (2004). The microbiology of cheese ripening. In P. F. Fox, P. L. H. McSweeney, T. M. Cogan, \& T. P. Guinee (Eds.), Cheese: Chemistry, physics and microbiology (pp. 287-317). London, UK: Elsevier Academic Press.

Bover-Cid, S., \& Holzapfel, W. H. (1999). Improved screening procedure for biogenic ammine production by lactic acid bacteria. International Journal of Food Microbiology, 53, 33-41.

Bover-Cid, S., Izquierdo-Pulido, M., \& Vidal-Carou, M. (2000). Mixed starter cultures to control biogenic amine production in dry fermented sausages. Journal of Food Protection, 63, 1556-1562.

Bover-Cid, S., Izquierdo-Pulido, M., \& Vidal-Carou, M. (2001). Effect of the interaction between a low tyramine-producing Lactobacillus and proteolytic staphylococci on biogenic amine production during ripening and storage of dry sausages. International Journal of Food Microbiology, 65, 113-123.

Bunková, L., Bunka, F., Mantlová, G., Cablová, A., Sedlácek, I., Svec, P., et al. (2010). The effect of ripening and storage conditions on the distribution of tyramine putrescine and cadaverine in Edam-cheese. Food Microbiology, 27, 880-888.

Burdychova, R., \& Komprda, T. (2007). Biogenic amine-forming microbial communities in cheese. FEMS Microbiology Letters, 276, 149-155.

Fernández, M., Linares, D., Del Rio, B., Ladero, V., \& Alvarez, M. (2007). HPLC quantification of biogenic amines in cheeses: correlation with PCR-detection of tyramine-producing microorganisms. Journal of Dairy Research, 74, 276-282.

Innocente, N., Biasutti, M., Padovese, M., \& Moret, S. (2007). Determination of biogenic amines in cheese using HPLC technique and direct derivatization of acid extract. Food Chemistry, 101, 1285-1289.

Innocente, N., \& D'Agostin, P. (2002). Formation of biogenic amines in a typical semihard Italian cheese. Journal of Food Protection, 9, 1498-1501.

Joosten, H. M. L. J., \& Northolt, M. D. (1998). Detection, growth, and amineproducing capacity of lactobacilli in cheese. Applied and Environmental Microbiology, 55, 2356-2359.

Kebary, K. M. K., El-Sonbaty, A. H., \& Badawi, R. M. (1999). Effects of heating milk and accelerating ripening of low fat Ras cheese on biogenic amines and free amino acids development. Food Chemistry, 64, 67-75.

Komprda, T., Burdychová, R., Dohnal, V., Cwiková, O., Sládková, P., \& Dvorácková, H. (2008). Tyramine production in Dutch-type semi-hard cheese from two different producers. Food Microbiology, 25, 219-227.

Ladero, V., Fernández, M., \& Álvarez, M. A. (2009). Effect of post-ripening processing on the histamine and histamine-producing bacteria contents of different cheeses. International Dairy Journal, 19, 759-762.

Latorre-Moratalla, M., Bover-Cid, S., Aymerich, T., Marcos, B., Vidal-Carou, M., \& Garriga, M. (2007). Aminogenesis control in fermented sausages manufactured with pressurized meat batter and starter culture. Meat Science, 75, 460-469.

Loizzo, M., Menichini, F., Picci, N., Puoci, F., Spizzirri, U., \& Restuccia, D. (2013). Technological aspects and analytical determination of biogenic amines in cheese. Trends in Food Science and Technology, 30, 38-55.

Mah, J. H., Kim, Y. J., \& Hwang, H. J. (2009). Inhibitory effects of garlic and other spices on biogenic amine production in Myeolchi-jeot, Korean salted and fermented anchovy product. Food Control, 20, 449-454.

Marcobal, A., De Las Rivas, B., Landete, J. M., Tabera, L., \& Muñoz, R. (2012). Tyramine and phenylethylamine biosynthesis by food bacteria. Critical Reviews in Food Science and Nutrition, 52, 448-467.

Marcobal, A., Martin-Alvarez, P. J., Moreno-Arribas, M. V., \& Muñoz, R. (2006). A multifactorial design for studying factors influencing growth and tyramine production of the lactic acid bacteria Lactobacillus brevis CECT 4669 and Enterococcus faecium BIFI-58. Research in Microbiology, 157, 417-424.

Marino, M., Maifreni, M., Bartolomeoli, I., \& Rondinini, G. (2008). Evaluation of amino acid-decarboxylative microbiota throughout the ripening of an Italian PDO cheese produced using different manufacturing practices. Journal of Applied Microbiology, 105, 540-549.

Martuscelli, M., Gardini, F., Torriani, S., Mastrocola, D., Serio, A., Chaves-López, C., et al. (2005). Production of biogenic amines during the ripening of Pecorino Abruzzese cheese. International Dairy Journal, 15, 571-578.

Mayer, H. K., Fiechter, G., \& Fischer, E. (2010). A new ultra-pressure liquid chromatography method for the determination of biogenic amines in cheese. Journal of Chromatography A, 1217, 3251-3257.

Moret, S., Bortolomeazzi, R., Feruglio, M., \& Lerker, G. (1992). Determination of biogenic amines in Italian cheeses. Scienza e Tecnica Lattiero-Casearia, 43 187-198.

Moret, S., Smela, D., Populin, T., \& Conte, L. S. (2005). A survey on free biogenic amine content of fresh and preserved vegetables. Food Chemistry, 89, 355-361.

Novella-Rodrìguez, S., Veciana-Noguès, M. T., Izquierdo-Pulido, M., \& VidalCarou, M. C. (2003). Distribution of biogenic amines and polyamines in cheese. Journal of Food Science, 68, 750-755. 
Novella-Rodrìguez, S., Veciana-Noguès, M. T., Trujillo-Mesa, A. J., \& VidalCarou, M. C. (2002). Profile of biogenic amines in goat cheese made from pasteurized and pressurized milks. Journal of Food Science, 68, 2940-2944.

Ordóñez, A. I., Ibanez, F. C., Torre, P., \& Barcina, Y. (1997). Formation of biogenic amines in Idiazabal ewe's-milk cheese: effect of ripening, pasteurization and starter. Journal of Food Protection, 60, 1371-1375.

Pinho, O., Pintado, A., Gomes, A., Pintado, M., Malcata, F., \& Ferreira, I. (2004). Interrelationships among microbiological, physicochemical, and biochemical properties of Terrincho cheese, with emphasis on biogenic amines. Journal of Food Protection, 7, 2779-2785.

Pintado, A. I. E., Pinho, O., Ferreira, I. M. P. L. V. O., Pintado, M. M. E., Gomes, A. M. P., \& Malcata, F. X. (2008). Microbiological, biochemical and biogenic amine profiles of Terrincho cheese manufactured in several dairy farms. International Dairy Journal, 18, 631-640.

Roig-Sagués, A. X., Molina, A. P., \& Hernández-Herrero, M. M. (2002). Histamine and tyramine-forming microorganisms in Spanish traditional cheeses. European Food Research and Technology, 215, 96-100.

Schirone, M., Tofalo, R., Fasoli, G., Perpetuini, G., Corsetti, A., Manetta, A. C., et al (2013). High content of biogenic amines in Pecorino cheeses. Food Microbiology, 34, 137-144.

Schneller, R., Good, P., \& Jenny, M. (1997). Influence of pasteurized milk, raw milk and different ripening cultures on biogenic amine concentrations in semi-soft cheeses during ripening. Zeitschrift für Lebensmittel-Untersuchung und -Forschung A, 204, 265-272.
Shalaby, A. (1996). Significance of biogenic amines to food safety and human health. Food Research International, 29, 675-690.

Silla Santos, M. (1996). Biogenic amines: their importance in foods. International Journal of Food Microbiology, 29, 213-231.

Siragusa, S., De Angelis, M., Di Cagno, R., Rizzello, C. G., Coda, R., \& Gobbetti, M. (2007) Synthesis of $\gamma$-aminobutyric acid by lactic acid bacteria isolated from a variety of Italian cheeses. Applied and Environmental Microbiology, 73, 7283-7290.

Spicka, J., Kalac, P., Bover-Cid, S., \& Krizek, M. (2002). Application of lactic acid bacteria starter cultures for decreasing the biogenic amine levels in sauerkraut European Food Research and Technology, 215, 509-514.

Spizzirri, G., Restuccia, D., Curcio, M., Parisi, O., Iemma, F., \& Picci, N. (2013). Determination of biogenic amines in different cheese samples by LC with evaporative light scattering detector. Journal of Food Composition and Analysis, $29,43-51$.

Stratton, J., Hutkins, R., \& Taylor, S. (1991). Biogenic amines in cheese and other fermented foods: a review. Journal of Food Protection, 54, 460-470.

Ten Brink, B., Damink, C., Joosten, H. M. L. J., \& Huis in't Veld, J. H. J. (1990), Occurrence and formation of biologically active amines in foods. International Journal of Food Microbiology, 11, 73-84.

Valsamaki, K., Michaelidou, A., \& Polychroniadou, A. (2000). Biogenic amine production in Feta cheese. Food Chemistry, 71, 259-266.

Yildiz, F., Yetisemiyen, A., Senel, E., Durlu-Özkaya, F., Öztekin, S., \& Sanli, E. (2010). Some properties of Civil cheese: a type of traditional Turkish cheese. International Journal of Dairy Technology, 63, 575-580. 